УДК 341.1/8

DOI https://doi.org/10.32849/2663-5313/2020.8.53

Інна Бойко,

канд. політ. наук, дочент,

доцент кафедри морсъкого права

Національного університету «Одеська морська академія»

\title{
МІЖНАРОДНО-ПРАВОВЕ РЕГУЛЮВАННЯ ПУБЛІЧНО-ПРИВАТНОГО ПАРТНЕРСТВА, ЗАРУБІЖНИЙ ДОСВІД ТА РЕФОРМА ПОРТОВОЇ ГАЛУЗІ УКРАЇНИ
}

Автор статті систематизувала досвід правового регулювання публічно-приватного партнерства та його реалізачії у процесі реформування портової галузі зарубіжними країнами з метою визначення переваг та ризиків впровадження моделі управління «порт-лендлорд» морськими портами України.

З'ясовано, що в Україні пілотні проєкти концесії реалізуються в портах без вирішення основної проблеми, що має передувати початку щвого прочесу, тобто наразі відсутня правова база для регулювання взаємин між АМПУ та землевласниками портів.

На прикладах нових країн-иленів СС доведено, що вибір на користь корпоративного управління портами, відповідно до настанов Організації економічної співпраці та розвитку та найкращої міжнародної практики, призводить до успішного результату. Акцентується на перевагах корпоратизованих портових адміністрацій: інвестиціях в інфраструктуру, орієнтованих на попит; максимізащії доходу від наявних активів; ринковому ціноутворенні; ращіоналізащії та покращенні контролю за операчіями.

Розглянуто досвід Естонії та Словенії, який підтверджує, що ефективне управління може бути як у випадку класичної моделі «порт-лендлорд», так і моделі порту послуг, при иьому, щоби зробити управління портами більш незалежним, $є$ два основні варіанти реформи: корпоратизація та приватизаиія.

Зроблено висновки, що: а) модель управління та експлуатащія великих вантажних портів «портлендлорд» передбачає наявність портової адміністрачії, яка здійснює контроль над портовим майном, розробляє політику використання земель, передає доступ до майна постачальникам послуг та інвесторам шляхом укладання довгострокових договорів (наприклад, кониесійних угод); б) для здійснення завдань щодо управляння портові адміністрачії мають стати автономними; в) управління української системи морських портів має здійснюватися відповідно до адаптованої до начіонального контексту моделі управління «порт-лендлорд», при иьому конкретний порт має розвиватись як окремий проєкт; г) перехід до моделі «порт-лендлорд» потребуватиме децентралізаиії, оскільки повноваження, які наразі розподілені між обласними адміністраціями, Міністерством інфраструктури України, ДП «АМПУ», стримують корпоративне управління портами.

Ключові слова: концепція публічно-приватного партнерства, модель управління портом, «порт-лендлорд», концесія, корпоратизація

Постановка проблеми. Фахівцями визнано, що сталий розвиток України у довгостроковій перспективі як постачальника основних продовольчих товарів, як імпортера та експортера контейнерних вантажів значною мірою залежить від здатності України планувати розвиток портів таким чином, щоб стимулювати ефективне використання земель, балансувати інтереси приватного та державного секторів та сприяти залученню приватних інвестицій [1, с. 7]. 26 червня 2020 року був підписаний перший в історії незалежної України концесійний договір між
Міністерством інфраструктури України, ДП «Адміністрація морських портів України», ТОВ «Рисоіл-Херсон» і ТОВ «Проєктна компанія Рисоіл-Херсон». Відповідно до договору концесіонеру ТОВ «Рисоіл-Херсон» протягом 30 років надається виключне право створювати, будувати і управляти Херсонським морським торговельним портом 3 метою його модернізації та подальшого розвитку. МІУ та ДП «АМПУ», передавши активи ДП «ХМТП» у концесію, стверджують, що таким чином проблема інвестування, модернізації об'єктів концесії, кваліфікованого управління 
ними та зростання бюджетних надходжень як від сплачених податків, так і від концесійних платежів вирішується [2].

Проаналізувавши досвід зарубіжних країн щодо реалізації завдань державно-приватного партнерства, фахівці (М. Бахуринська [3], А. Бакстер [13], П. Верховен [12], В. Власова [4], С. Грищенко [5], Н. Дутко [6], О. Карпенко [7], Л. Ніколаєва [8, с. 250], Т. Ноттебоум [12], О. Родіонова [9], Дж. Стартін [13], М. Фонтане [12], Н. Хардінг [13], Л. Шарінген [10], В. Шемаєв [11]) вважають, що концесія як форма партнерства держави та приватного капіталу в морських портах є одним із найважливіших способів підвищення ефективності інфраструктури, який дозволяє швидко залучати значні інвестиції в економіку. Вченими розроблена класифікація моделей правових режимів державно-приватного партнерства за критерієм структури правового забезпечення державно-приватного партнерства (публічно-приватне партнерство або приватна фінансова ініціатива), аналіз яких доводить, що необхідно враховувати не лише ефективність апробації певних моделей в інших країнах, але і національні особливості (нормативно-правова база; соціально-економічний розвиток країни; рівень добробуту населення, який включає платоспроможність; рівень корупції) [9; 14, с. 179].

Мета статті - систематизувати досвід правового регулювання публічно-приватного партнерства та його реалізації у процесі реформування портової галузі зарубіжними країнами та визначити переваги та ризики впровадження моделі управління «порт-лендлорд» морськими портами України.

Виклад основного матеріалу. Міжнародна практика постійно уточнює концепцію державно (публічно)-приватного партнерства (далі - ДПП) завдяки правотворчій діяльності міжнародних інституцій, таких як Європейська комісія, Комісія ООН з міжнародного торгового права (UNCITRAL). Визначення ДПП, сформульоване Європейською комісією в «Зеленій книзі» $Є С$ щодо ДПП, акцентує, що державно-приватне партнерство - це різноманітні «форми співпраці між органами державної влади та діловим співтовариством, метою якої є забезпечення фінансування, будівництва, реконструкції, управління й обслуговування інфраструктури чи надання послуг» [15]. UNCITRAL надає визначення різнім формам контрактів, які застосовуються у реалізації проєктів ДПП: концесії, ліцензії, лізинг, ВОТ (buildoperate-transfer /будівництво-експлуата- ція-передача), ВТО (build-transfer-operate/ будівництво-передача-експлуатація), BROT (build-rent-operate-transfer/будівництвооренда-експлуатація-передача) або BLOT (build-lease-operate-transfer/будівництвовинаєм-експлуатація-передача), BOOT (build-own-operate-transfer/будівництвовласність-експлуатація-передача). Крім абревіатур, які використовуються для виділення конкретного режиму власності, інші можуть бути використані для підкреслення одного або декількох зобов'язань концесіонера. У деяких проєктах навявні інфраструктурні об'єкти передаються приватним структурам для модернізації або реконструкції, експлуатації та обслуговування, постійно або протягом певного періоду часу. Залежно від того, чи буде приватний сектор власником такого інфраструктурного об'єкта, ці домовленості можутьназиватися «оновлення-експлуатаціяпередача»/《refurbish-operate-transfer» (ROT) або «модернізація-експлуатація-передача» / «modernize-operate-transfer» (MOT) в першому випадку, або «оновлення-власністьексплуатація»/《refurbish-own-operate» (ROO) або «модернізація-експлуатація»/ «modernize-own-operate» (MOO) - в останньому. Вираз «проєктування-будуванняфінансування-експлуатація»/ «designbuild-finance-operate» (DBFO) іноді використовується для підкреслення додаткової відповідальності концесіонера за проєктування об'єкта та фінансування його будівництва [16, р. 20].

У травні 2019 року Секретаріатом Свропейської організації морських портів (ESPO) прийнятий Меморандум по портові галузі європейських країн [17]. Враховуючи, що Україна реформує портову галузь, орієнтуючись ннасамперед на досвід цих держав, охарактеризуємо зміст десяти принципів розвитку портової галузі, які закріплює Меморандум. Відповідно до пріоритету № 1 адміністрації портів у Європі є ключовим елементом портової системи, оскільки є комунікаторами між клієнтами, портовим співтовариством та широким рядом стейкхолдерів. Оновлене регулювання портових послуг встановлює принципи прозорого фінансування, що надходить від державного бюджету, та передбачає базові умови залучення стейкхолдерів та суб'єктів господарювання в портах. У тому числі передбачається право адміністрації порту самостійно визначати розмір та структуру зборів для розвитку портової інфраструктури та можливість вести індивідуальні перемови зі своїми клієнтами. Пріоритет № 2 фіксує, що портові адміністративні органи продовжують бути гібридними: з одного боку, вони стають більш автономними та комер- 
ційно орієнтованими, з іншого - виконують громадські завдання та беруть на себе більше соціальних зобов'язань. При цьому мала частина європейських портів належить приватним суб'єктам, більша частина управляється адміністраціями, акції яких належать різним рівням влади. Структура портових доходів складається 3 портових зборів, концесійних платежів, доступу до причалу та іноді від надання послуг з операційної діяльності. У зв'язку з цим портові збори повинні розглядатися як суттєві доходи для адміністрацій портів, оскільки вони становлять до половини доходів портів. Тому знижки, що надаються портовими адміністраціями на портові збори для певних категорій суден у межах своїх фінансових можливостей, повинні тлумачитись як добровільне, індивідуальне рішення адміністрацій портів відповідно до стратегії порту, регіональних пріоритетів (наприклад, екологічних проблем). Пріоритетом № 3 визначається, що інвестування в європейські порти є інвестуванням у конкурентоздатність Європи. Нині інвестиційні потреби європейських портів сягають 48 млрд на найближчі десять років, при цьому $65 \%$ інвестицій потребують основні інфраструктурні об'єкти, включаючи інфраструктуру морського доступу та транспортне сполучення 3 внутрішніми територіями Свропи. Відповідно до пріоритету № 4 ключовим зв'язком між портами та логістичними центрами країн $€$ мультимодальне сполучення. Базуючись на керівних принципах Транс'європейської транспортної мережи (TEN-T) до 31 грудня 2030 року, основні морські порти повинні бути з'єднані із залізницею, автомобільною дорогою та, де це можливо, внутрішнім водним транспортом. У зв'язку з цим $18 \%$ інвестиційних проєктів, запланованих адміністраціями портів у найближчі десять років, є проєктами транспортного сполучення із внутрішніми територіями та розвитку інфраструктури для безперешкодного мультимодального сполучення в порту. Додаткові 5 \% проєктів стосуються інвестицій в інтермодальні/мультимодальні термінали в портовій зоні та за їі межами. Пріоритетом № 5 визначено роль та значущість діджіталізації у забезпеченні захисту, безпеки, екологічної тощо. Крім того, одним із пріоритетів діджиталізації є впровадження European Maritime Single Window Environment у співробітництві між владою, морськими та митними органами на національному та на рівні $\mathrm{CC}$, що унормуе та спростить взаємозв'язок між учасниками логістичних ланцюжків постачання. Пріоритет № 6 пов'язаний 3 необхідністю проведення заходів щодо декарбонізації. Зокрема, зазначається, що Міжнародна морська орга- нізація (IMO) повинна розробити стратегію та заходи для переходу до відновлювальної енергетики, енергоефективного та сталого розвитку, що зменшить викиди вуглекислого газу та використання невідновлюваних енергоресурсів. Додатково планується посилити інвестиції в порти, які сприяють зміцненню ролі та впровадженню альтернативних видів палива та джерел енергії в економіці та суспільному житті. Для портового сектора важливим є розгортання заходів щодо скорочення викидів відповідно до програм, цілей та планів щодо декарбонізації. Крім того, програма енергетичного переходу може запропонувати нові можливості для бізнесу в певних портах (відновлювані джерела енергії, біопромисловість, розвиток біоелектростанцій з уловлювання та зберігання вуглецю). Окремо визначено зміст наступного пріоритету: якість повітря в центрі відносин між портами та містами. Протягом останніх чотирьох років якість повітря є головним екологічним пріоритетом європейських адміністрацій портів у відносинах з містами. 3 огляду на зниження викидів $\mathrm{SOx}, \mathrm{NOx}$ та $\mathrm{CO} 2$, необхідно розробити поступовий, але обов'язковий план переходу до більш чистих видів палива, що забезпечує як якість повітря, так і декарбонізацію. Пріоритет № 8 стосується завдання портів щодо сприяння відкритому торговому середовищу, оскільки через морські порти здійснюється близько 75 \% торгівлі Свропи зі світом та більше однієї третини внутрішньо-європейської торгівлі. ESPO вважає, що опубліковані 12 березня 2019 року принципи та умови взаємодії між ЄС та Китаєм є конкретною стратегією, що повинна бути реалізована найближчим часом для сприяння двосторонній торгівлі. Відповідно до пріоритету № 9 порти і громадяни повинні мати право на діяльність, тобто європейські порти можуть функціонувати і розвиватися лише в тому разі, якщо вони отримують право на діяльність від місцевої громади. Щоб отримати це право, вони повинні бути прозорими щодо свої діяльності, впливу на навколишнє середовище, а також щодо їхньої ролі та внеску у вирішення наявних проблем. Сьогодні все більше і більше європейські порти демонструють свою прозорість та природоохоронну діяльність через незалежну оцінку третьої сторони та аудит. Пріоритетом № 10 наголошується необхідність узгодження та координації дій щодо розробки та впровадження транспортної політики на рівні ЄС (навколишнє середовище, митниця, конкуренція, енергетика, морські справи, дослідження) [17].

Досвід реформування портової діяльності та державного регулювання щодо створення сприятливих умов із розвитку 
портової інфраструктури портів Гамбург (Німеччина), Роттердам (Нідерланди), Антверпен (Бельгія), Ле Гавр (Франція) заслуговує на запозичення, зокрема, 3 метою створення сприятливих умов щодо розвитку портової інфраструктури відповідні держави використовують такий інструмент, як модель земельних концесій «порт-лендлорд», коли портова адміністрація виступає в ролі лендлорда, у розпорядженні якого перебувають землі в межах акваторій портів. Окрім цього, портові адміністрації несуть відповідальність за стратегічні об'єкти інфраструктури (доки, мости, шлюзи, причали, землі), безпеку судноплавства та навігацію в порту, стимулювання міжнародної торгівлі та маркетингову діяльність. При цьому приватні портові оператори здійснюють стивідорну діяльність на землях і причалах, отриманих у концесію терміном до 40 років із правом її подальшого продовження [11, с. 122].

Більшість портів у світі можна класифікувати за моделлю управління та віднести до однієї з чотирьох категорій: (а) державні порти, де держава одночасно є власником або іншим чином контролює використання портових земель, інфраструктури і термінальних потужностей та надає послуги 3 обробки вантажів (наприклад, словенський порт Копер); (б) порти-інструменти, де держава $є$ власником або іншим чином контролює використання портових земель, інфраструктури та термінальних потужностей, але передає надання послуг операторам приватного сектора (наприклад, порт Читтагонг у Бангладеш); (в) порти-лендлорди, де держава $є$ власником або іншим чином контролює використання портових земель і передає право на розвиток термінальних потужностей порту, іноді й інфраструктури, та укладає договори щодо надання послуг 3 перевезення вантажів із приватним сектором або корпоративними операторами на підставі довгострокових домовленостей, як правило, це концесійна угода (приклади портів Сінгапуру та Роттердама); (г) приватні порти, де приватні інвестори володіють портовими землями, інфраструктурою та термінальними потужностями, а також надають послуги з обробки вантажів і транспортних засобів (наприклад, Британський порт Феліксстоу). Серед цих моделей управління поширеною в міжнародній практиці є модель «порт-лендлорд». Модель «порт-лендлорд» передбачає, що портові адміністрації не беруть безпосередньої участі в наданні операційних послуг, а виконують функції землевласника, регулятора та менеджера громади. Основна особливість ролі оператора полягає у наданні та нагляді за концесіями, договорами оренди та/або ліцензіями незалежним постачальникам послуг. Фахівцями Світового банку підраховано, що майже 90 \% світових контейнерних терміналів організовані як порти-лендлорди, де державні органи управління портами та приватні оператори контейнерних терміналів функціонують відповідно до концесійних угод або за довгостроковою орендою [1, с. 12].

За даними консультантів Світового банку, ситуація в українських портах не вкладається в жодну з чотирьох класичних моделей функціонування портової галузі. На прикладі порту Південний експерти проілюстрували, що земельні відносини при реалізації інвестиційних проєктів у портах можуть бути ускладненими тим, що перспективні ділянки для забудови належать різним органам місцевої влади (комунальні) обласній адміністрації (державні), приватним суб'єктам [1, с. 14]. Земельні концесії у європейських портах віддалено нагадують орендні відносини в українських портах; різниця в тому, що в Україні у процедурі передачі земельних ділянок і майна вітчизняні

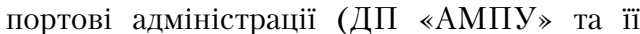
філії) виконують другорядну роль [11, с. 123].

В Україні пілотні проєкти концесії реалізуються в портах без вирішення основної проблеми, що має передувати початку цього процесу, вважають експерти [1, с. 13]. Суть справи полягає у взаєминах між АМПУ та нинішніми землевласниками. Приклади нових країн-членів $С$ С ілюструють успіх внаслідок зробленого вибору на користь корпоративного управління відповідно до настанов Організації економічної співпраці та розвитку (OECD) та найкращої міжнародної практики [19]. Випадки Естонії та Словенії доводять, що ефективне управління може статися як у випадку класичної конфігурації землевласника, так і моделі порту послуг. Досвід Словенії, єдиний торговельний порт якої інтегрально керується акціонерним товариством «Лука Копер», при цьому держава - Республіка Словенія - виступає мажоритарним акціонером, заслуговує на вивчення. Акціонерне товариство має довгострокову концесію від держави. Концесійний договір «Лука Копер» був укладений у 2008 році терміном на 35 років, як це передбачено Морським кодексом Словенії [20]. Концесійна угода стосується питань, пов'язаних 3 портовою діяльністю, управлінням, розвитком та обслуговуванням портової інфраструктури. Узгоджений концесійний збір становить 3,5 \% від виручки від продажу «Лука Копер», виключаючи дохід від портових зборів. Також концесійний збір включає право на користування водою, плату за воду та інші мита, пов'язані з використанням акваторії, що належить дер- 
жаві. ТОВ «Лука Копер» сплачує загальний концесійний збір Республіці Словенія, яка потім виділяє половину суми двом місцевим громадам: муніципалітету Копер та муніципалітету Анкаран (з 1 січня 2015 р.). Крім того, дочірні компанії ТОВ «Лука Копер» керують внутрішнім терміналом у Сежані та логістичним центром і контейнерним терміналом в Араді (Румунія), надають приватні залізничні послуги для ринків Словенії, Австрії та Німеччини, а також виконують роботи з днопоглиблення [21].

Діяльність естонських портів (реєстр державних портів Естонії включає 217 портів і гаваней) регулюється Законом про порти, який набув чинності 10 липня 2009 р. [22]. Більшість портів не $є$ комерційними, вони включають пристані для яхт, риболовецькі порти або це порти, що забезпечують місцеве транспортне сполучення. Таллінн є найбільшим (складається з п'яти окремих портових зон) і найрозвиненішим торговельним портом в Естонії: на нього припадає близько 60 \% усіх комерційних вантажів. Він був уперше реструктуруваний в середині $1990-$ х років 3 метою перетворення його з державного порту на порт-лендлорд. У 1999 році останній перевантажувальний термінал був приватизований. Сьогодні порт Таллінна працюе за моделлю порту-лендлорду. Основна мета портової адміністрації - розвиток базової та експлуатаційної інфраструктури, передача портових земель операторам для стимулювання інвестицій у термінальні потужності та технології [23]. Портова адміністрація була корпоратизована у 2018 році. Сьогодні акції портового відомства котируються на Талліннській фондовій біржі, 67 \% акцій належать урядові Естонії, решта - інвестиційним та пенсійним фондам та приватним інвесторам. Порт розвивається згідно з Генеральним планом, який включає детальне планування всіх портових територій з урахуванням економічних, соціальних та екологічних інтересів Таллінна. Промислові та логістичні парки розташовані та функціонують в окремих портових зонах [24].

Як бачимо, для того щоб зробити управління портами більш незалежним, $є$ два основні варіанти реформи: корпоратизація та приватизація. Завдяки корпоратизації власність портової адміністрації залишається в руках уряду, який стає акціонером. Приватизація передає фактичну власність приватному підприємству або у формі повної власності на портове майно, або через довгострокову основну концесію. Вибір між корпоратизацією та приватизацією буде залежати від обрисів, яких захоче набути портова адміністрація, що, своєю чергою, залежить від експлуатаційної конфігурації та типу порту [18]. Основні ознаки та переваги корпоратизованих портових адміністрацій узагальнено: а) ознаки (фінансова самоокупність; відданість ідеї розвивати порти на підставі потреб бізнесу; широка операційна діяльність відповідно до моделі «порт-лендлорд»; наділення повноваженнями вести переговори та підписувати довгострокові договори оренди чи концесії; б) переваги (інвестиції в інфраструктуру, орієнтовані на попит; максимізація доходу від наявних активів; ринкове ціноутворення; раціоналізація та покращення контролю за операціями) [1, с. 25].

Міжнародні експерти визнають потенційними ризиками, які пов'язані із моделлю управління «порт-лендлорд», таке: а) якщо портові адміністрації неналежним чином оцінюють пропозиції, ініційовані інвесторами, то вони ризикують прийняти занадто багато проєктів, що може призвести до надмірної «терміналізації» або фрагментації портової зони; б) портові адміністрації повинні юридично визнати межі своїх повноважень і співпрацювати 3 муніципальними, регіональними та національними урядовими структурами; в) слід враховувати, що ця модель заохочує розвиток на рівні окремих портів, тому необов'язково вона може бути найкращою моделлю для національної мережі портів, а отже, потрібні інституційні механізми для урівноваження місцевих та державних інтересів (наприклад, створення провідного агентства для портів на рівні держави); г) для впровадження моделі може знадобитися регулятор, особливо коли в системі відсутня конкуренція між портами i/або всередині портів: регулятор необов’язково може бути тим самим органом, що й провідне державне агентство, а виконання цієї ролі потребує накопичення досвіду з плином часу заради отримання легітимності на ринку; г) ця модель не заважає концесіонерам самим бути державними підприємствами (наприклад, це поширено в Азії).

\section{Висновки}

Отже, можна дійти таких висновків: а) модель управління та експлуатація великих вантажних портів «порт-лендлорд» передбачає наявність портової адміністрації, яка здійснює контроль над портовим майном, розробляє політику використання земель, передає доступ до майна постачальникам послуг та інвесторам шляхом укладання довгострокових договорів (наприклад, концесійних угод); б) для здійснення завдань щодо управляння портові адміністрації мають стати автономними; в) управління української системи морських портів має 
здійснюватися відповідно до адаптованої до національного контексту моделі управління «порт-лендлорд», при цьому конкретний порт має розвиватись як окремий проєкт; г) перехід до моделі «порт-лендлорд» потребуватиме децентралізації, оскільки повноваження, які наразі розподілені між обласними адміністраціями, Міністерством інфраструктури України, ДП «АМПУ », стримують корпоративне управління портами.

\section{Список використаних джерел:}

1. Вдосконалення управління портовою галуззю України. Звіт Світового банку. Київ, $2020.76 \mathrm{c}$.

2. Підписано перший договір концесії морського порту в Україні. URL: https:// investinkherson.gov.ua/news/pidpisano-pershijdogovir-konczesi\%D1\%97-morskogo-portu-vukra\%D1\%97ni/ (дата звернення: 15.06.2020).

3. Бахуринська M. Порівняльний аналіз правового регулювання процедури вибору приватного партнера на умовах ДПП на прикладі Польщі. Підприємництво, господарство $і$ право. 2017. № 5. C. $81-85$;

4. Власова В.П. Світовий досвід та перспективи впровадження державно-приватного партнерства в морських торговельних портах України Збірник наукових пращь Таврійського державного агротехнологічного університету (економічні науки). 2014. № 4(28). С. 24-27.

5. Грищенко С. Підготовка та реалізація проектів публічно-приватного партнерства : практичний посібник для органів місцевої влади та бізнесу. Київ : ФОП Москаленко О., 2011.140 с.

6. ДуткоН.Г.Концесія,якперспективнаформа державно-приватного партнерства. Державне управління: удосконалення та розвиток. 2020. № 3. URL: http://www.dy.nayka.com.ua/?op $=1 \& z=1597$. DOI: 10.32702/2307-2156-2020.3.31 (дата звернення: 15.06.2020).

7. Карпенко О.О. Аналіз європейського досвіду впровадження концесійної форми державно-приватного партнерства у морських портах. Бізнес Інформ. 2015. № 6. С. 43-47.

8. Ніколаєва Л.Л. Розвиток портів України: організаційне та інвестиційне забезпечення. Вісник Приазовського державного технічного університету. Серія «Економічні науки». 2017. Вип. 34. С. 2 45-251.

9. Родионова О.Ю. Зарубежный опыт и модели правового регулирования публично-правового партнерства. Вестник РУДН. 2014. № 2. C. $221-228$

10. Шарингер Л. Новая модель инвестиционного партнерства государства и частного сектора. Российский экономический журнал. 2004. № 9/10. С. 41-52.

11. Шемаєв В.В. Від Антверпена до Роттердама: європейський досвід управління розвитком портової інфраструктури для морегосподарського комплексу України). Стратегічні пріоритети. № 2 (43), 2017. C. $120-128$
12. Notteboom T.E., Verhoeven P. and Fontanet M. Current practices in European ports on the awarding of seaport terminals to private operators: towards an industry good practice guide. Maritime Policy \& Management. 2012. № 39 (1). P. 107-123.

13. Startin J., Baxter A, and Harding N. Comparing public-private partnerships for highway projects in the USA and the UK/EU: Applying lessons learned. Journal of Public Works E्Infrastructure. 2009. Vol. 1. №. 4. P. 329-348.

14. Хусаінов Р. Моделі державно-приватного партнерства: закордонний досвід та перспективи для України. Науковий вісник Одеського економіч ного університету. 2015. № 1 (4).С. 177-191.

15. Green Paper on public-private partnerships and Community law on public contracts and concessions Brussels, 30.4.2004. COM(2004) 327 final. URL: https://op.europa.eu/en/publicationdetail/-/publication/94a3f02f-ab6a-47edb6b2-7de60830625e/language-en (дата звернення: 15.06.2020)

16. UNCITRAL Model Legislative Provisions on Privately Financed Infrastructure Projects. URL: https://https://www.uncitral.org/pdf/english/ texts/procurem/pfip/guide/pfip-e.pdf (дата звернення: 15.06.2020).

17. Priorities of European Ports for 2019-2024. What ports do for Europe.What Europe can do for ports URL: https://www.espo.be/media/ESP2484\%20(Memorandum\%20ESPO\%202019) DEF_LR.pdf (дата звернення: 15.06.2020).

18. Patrick Verhoeven \& Thomas Vanoutrive. A quantitative analysis of European port governance. Maritime Economics \& Logistics. 2012. Vol. 14. P. 178-203.

19. Strategic Transport Infrastructure Needs to 2030 Main Findings. International Futures Programme. OECD, 2011. URL: https://www.oecd.org/futures/ infrastructureto2030/49094448.pdf (дата звернення: 25.06.2020).

20. Maritime Code (PZ). Official Gazette of the Republic of Slovenia No 26 of 12 April 2001 page 2677. URL:https://www.un.org/Depts/los/ LEGISLATIONANDTREATIES/PDFFILES/ SVN_2001_maritimecode.pdf (дата звернення: $25.06 .2020 \overline{)}$

21. Port of Koper is fully operational. April 3, 2020. URL: https://www.portseurope.com/port-ofkoper-is-fully-operational-april-3-2020/ (дата звернення: 25.06.2020).

22. Ports Act. Passed 15.06.2009, entry into force 10.07.2009. URL: https://www.riigiteataja.ee/ en/eli/523052018004/consolide (дата звернення: 25.06.2020).

23. Development plans Port of Tallinn aims to become the most innovative port on the shores of the Baltic Sea by offering its customers the best environment and development opportunities. URL: https://www.ts.ee/en/development-plans/ (дата звернення: 25.06.2020).

24. Port of Tallinn. We develop attractive real estate and industrial parks in our harbour areas. URL https://www.ts.ee/en/real-estate-development/ (дата звернення: 18.06.2020) 
Inna Boyko. International legal regulation of public-private partnership, foreign experience and reform of the port industry in Ukraine

The author of the article systematized the experience of legal regulation of public-private partnership and its implementation in the reform of the port industry by foreign countries in order to determine the benefits and risks of implementing the management model "port-landlord" seaports of Ukraine.

The examples of the new EUmemberstates have shown that the choice in favorof corporate portmanagement in accordance with the guidelines of the Organization for Economic Cooperation and Development and best international practice, leads to a successful outcome. Emphasis is placed on the advantages of corporatized port administrations: demand-oriented infrastructure investments; maximizing income from available assets; market pricing; streamlining and improving control over operations.

The experience of Estonia and Slovenia is considered, which confirms that effective management can occur both in the case of the classic model "port landlord" and the model of the port of services, there are two main reform options to make port management more independent: corporatization and privatization.

It is concluded that a) the model of management and operation of large cargo ports "Port Landlord" provides for the presence of the port administration, which controls port property, develops land use policy, transfers access to property to service providers and investors by concluding long-term contracts (eg, concession agreements); b) port administrations must become autonomous to carry out management tasks; c) the management of the Ukrainian seaport system should be carried out in accordance with the port-land management model adapted to the national context, while a specific port should be developed as a separate project; $d$ ) the transition to the "port-landlord" model will require decentralization, as the powers currently distributed between the regional administrations, the Ministry of Infrastructure of Ukraine, and the State Enterprise "Ukrainian Sea Ports Authority" constrain the corporate management of ports.

Key words: concept of public-private partnership, private finance initiative, port management model, "port-landlord", concession, corporatization. 